\title{
SCHOOL FACTORS AFFECTING ESTONIAN STUDENTS' SUBJECTIVE WELL-BEING AT THE BASIC SCHOOL
}

\author{
PROBLEMS \\ OF EDUCATION \\ IN THE $21^{\text {st }}$ CENTURY \\ Vol. 75, No. 6, 2017
}

\author{
Marika Ratnik, Eha Rüütel \\ Tallinn University, Estonia \\ E-mail: marika.ratnik@mail.ee, eha@tlu.ee
}

\begin{abstract}
This research focuses on the personal well-being of basic school students and on the school environment factors affecting it. The authors were also interested to know whether there are any differences between two age groups ( $6^{\text {th }}$ grade and $9^{\text {th }}$ grade) in the perception of the school environment and school relations. The research included 934 students (426 boys and 508 girls) aged 12 to 17 years. The well-being was measured by the WHO-5 Well-Being Index; school factors included perceived school relationships, perceived learning environment and academic performance. The indicators differentiating between the groups with low and high well-being were: obtaining help from the school, the pleasantness of lessons, relationships with teachers, and relationships with schoolmates. In both age groups, higher well-being was predicted by relationships with teachers and schoolmates, obtaining help from the school, and parents' relationships with the school. The results indicated that students establish relationships supporting their well-being not only in their class. It is rather the wider communication culture in the school that supports the students' well-being. The results also indicate the wider effect of school relationships in that the factor of obtaining help from the school (the school's pro-social organization) is more significant for the students'well-being that the pro-social behaviour of the classmates.
\end{abstract}

Keywords: adolescence academic performance, perceived school relationships, perceived learning environment, subjective well-being.

\section{Introduction}

Students may be better experts in matters related to school life than adults. It is important to identify and account for the students' opinions, and to provide students with the sense of involvement in school improvement. The monitoring of children's rights and parenting in Estonia indicated that children are mostly able to participate in the solving of matters related to their home and family and able to have a say in their personal matters, but that they have significantly less opportunities to express their opinion in relation with their school environment (Laes, Krusell, Reinomägi \& Toros, 2013). Among the children, 34\% have been able to have a say in the organization of school events, $24 \%$ in the establishment of their school's rules, $21 \%$ in the setting of the amount of homework, and $15 \%$ in the choice of school meals (Karu, Turk, Suvi \& Biin, 2012). Regular internal and external audits are performed in Estonian schools, but the tradition of asking children themselves about their opinion of their school environment, disclosing it to the public, and learning from it is hard to develop (Ilves, 2013). This is why the article focuses on the students' own assessment on the school factors affecting their well-being.

\section{The Well-Being of Estonian Basic School Students with their Life and School}

In the international study of students' health behaviour in 2013/2014 where 42 countries participated, the Estonian general indicator of students' satisfaction with their life was ranked 15th among 11 years old students, 7th among 13 years old students and 17th among 15 years 
PROBLEMS

OF EDUCATION

IN THE $21^{\text {st }}$ CENTURY Vol. 75, No. 6,2017

600

old students (Inchley et al., 2016), being in the top half of the results. Satisfaction with one's life reflects satisfaction with one's living environment, health, emotional state and opportunities in life. As education and the school are important in the life of adolescents, their satisfaction with life is related with their behaviour and experiences in the school and with their attitudes toward their school environment (Salmela-Aro \& Tuominen-Soini, 2010). Based on the data of the aforementioned study, Estonian students' enjoyment in attending school among the participating 42 countries was ranked the last for 11 and 13 years old students and the last but one for 15 years old students (Inchley et al., 2016). Looking at that indicator as percentages of 11-15 years old students participating in the research $(n=4,808)$, it becomes clear that $62 \%$ of them liked or rather liked attending school and 38\% rather did not like it or did not like it at all (Aasvee et al., 2016).

The enjoyment of school is used to define the level of satisfaction with the school (Huebner, 1994). Satisfaction with the school is one of the contextual factors of students' subjective well-being and studies have shown that students tend to be more dissatisfied with their school than with their family, friends, themselves, their living environment, or their life as a whole (Huebner, Gilman, Reschly \& Hall, 2009). Therefore, the difference between the satisfaction with their life and the satisfaction with their school, shown in the results of the research, is nothing extraordinary. Yet, issues are raised by Estonian students' ranking as the last places among countries where student's enjoyment of their school was asked.

\section{Theoretical Background: Students' Subjective Well-Being and their Well-Being at School}

Subjective well-being is defined through emotional state. Diener (1984) has defined subjective well-being as a multi-dimensional construct including both positive (joy) and negative (anger, sadness) affects and cognitive assessment of life in general (overall satisfaction with life) and/or to specific fields like the school environment's good and bad aspects or family relationships. Konu, Lintonen and Rimpelä (2002) presented a conceptual model of wellbeing at school, describing the specific school conditions related with well-being: the physical environment (the timetable, the study load, the size of study groups, punishments, the school's level of security, the school's health services, school meals); the school relationships (the climate at school, group relationships, student-teacher relationships, the relationships with same-age schoolmates, school bullying, home-school co-operation, the acceptance of students, teachers' level of interest toward the students' life, obtaining help from the school); self-realisation opportunities (valuing the work of students, encouragement, possibilities to participate in deciding the matters pertaining to school life, supporting self-worth and creativity, free time activities in the school). Beside the school conditions, the student's health (falling ill, chronic illnesses, overall state of health, health behaviour) is also important in the model. On the other hand, Engels, Aelterman, Van Petegem and Schepens (2004) highlight the positive emotional state resulting from the meeting of personal needs and expectations as a factor of students' well-being. Noble, McGrath, Wyatt, Carbines and Robb (2008) relate the student's well-being to personal factors: experiencing mainly positive feelings and attitudes; pro-social behaviour towards schoolmates and teachers; strength of personality; an optimistic concept of self and satisfaction with learning experiences.

Students perceiving school factors as positive also give higher assessments to their subjective well-being (Liu, Mei, Tian \& Huebner, 2016; Pilkauskaite-Valickiene \& Gabrialaviciute, 2015; Tian, 2008; Tian, Liu, Huang \& Huebner, 2013), they cope better with the school's challenges and are more engaged in learning (Salmela-Aro \& Tuominen-Soini 2010). However, Salmela-Aro, Moeller, Schneider, Spicer and Lavonen (2016) stress that positive and negative aspects of engagement should be studied and modeled together as some 
students experienced elevated levels of both engagement and burnout. Their study revealed that resources experienced at school were related to situational and stable measures of engagement, while demands were related to burnout.

\section{Previous Research: School Factors Affecting Subjective Well-Being}

The adolescent years are an important time in shaping one's personal identity, therefore the subjective well-being is influenced by the school social relationships (Eccles \& Roeser, 2011), positive student-teacher relationships (Liu et al., 2016; Suldo, Shaffer \& Riley, 2008; Suldo et al., 2009), social support experienced at school (Tian, Zhao \& Huebner, 2015), support by teachers and specific help obtained from teachers (Bird \& Markel, 2012; Simmons, Graham \& Thomas, 2015). The student's well-being is also connected to the relationships between students: with classmates (Liu et al., 2016; Tian et al., 2015), with same-age schoolmates (Uusitalo-Malmivaara, 2012), with friends at school (Casas, Baltatescu, Bertran, Gonzales \& Hatos, 2013), with bullying behaviour present at school (Gobina, Zaborskis, Pudule, Kalnins \& Villerusa, 2008; Tiliouine, 2015).

Concerning the learning environment, the following factors have been highlighted as those affecting well-being: the students' involvement in decision-making processes (Engels, et al, 2004; Lewis, Huebner, Malone \& Valois, 2011); fair treatment based on the school's rules (Samdal, Nutbeam, Wold \& Kannas, 1998); the school's level of security (Samdal, et al., 1998); behavioural and emotional engagement (Li \& Lerner, 2011). As a separate factor, academic results have been highlighted (Gilman \& Huebner, 2006; Soutter, 2011).

In a Holfve-Sable (2014) study where 6th year students participated $(n=1,540)$, their subjective well-being depended the most on three factors: the student's relationships with teachers, the student's relationships with other students, and the student's learning experience i.e. satisfaction with the learning climate. A study conducted in the U.S. among 5th and 7th year students $(n=1,286)$, their subjective well-being was predicted by their satisfaction with the school, containing the students' assessments to their class relationships, grades, school experience, and the school's quality in general (Newland, Lawler, Giger, Roh \& Carr, 2015). A study by Pilkauskaite-Valickiene and Gabrialaviciute (2015) indicated that the level of wellbeing among students (aged 15-19 years) differs with regard to their attachment to school, teacher support and open classroom climate for discussions.

Similar to this research, Tian et al. (2013) has compared students in various age groups. The sample was formed of 13-16 years old students. For younger students, their well-being at school was predicted by social support from teachers and parents; for older students, their well-being at school was predicted by support from teachers and friends. Those indicators also characterised positive feelings toward the school. But in general, wider studies of students' satisfaction with life have shown that any differences by age or demography are small (Huebner et al., 2009).

\section{The Aim of this Research}

International research regarding school students, conducted in recent years (20132014), indicate that Estonian students are rather at the bottom of the ranking list of school attendance enjoyment. Yet, substantive changes have been introduced in schools since 2010, such as developing support systems, involving students in the organization of school life, and involving students with special needs in ordinary school. Based on that, this research has aimed at observing certain school factors and their role in shaping the school well-being, so as to get a better understanding of and highlight those aspects of the school life that influence students the most. 
Marika RATNIK, Eha RÜÜTEL. School factors affecting Estonian students' subjective well-being at the basic school

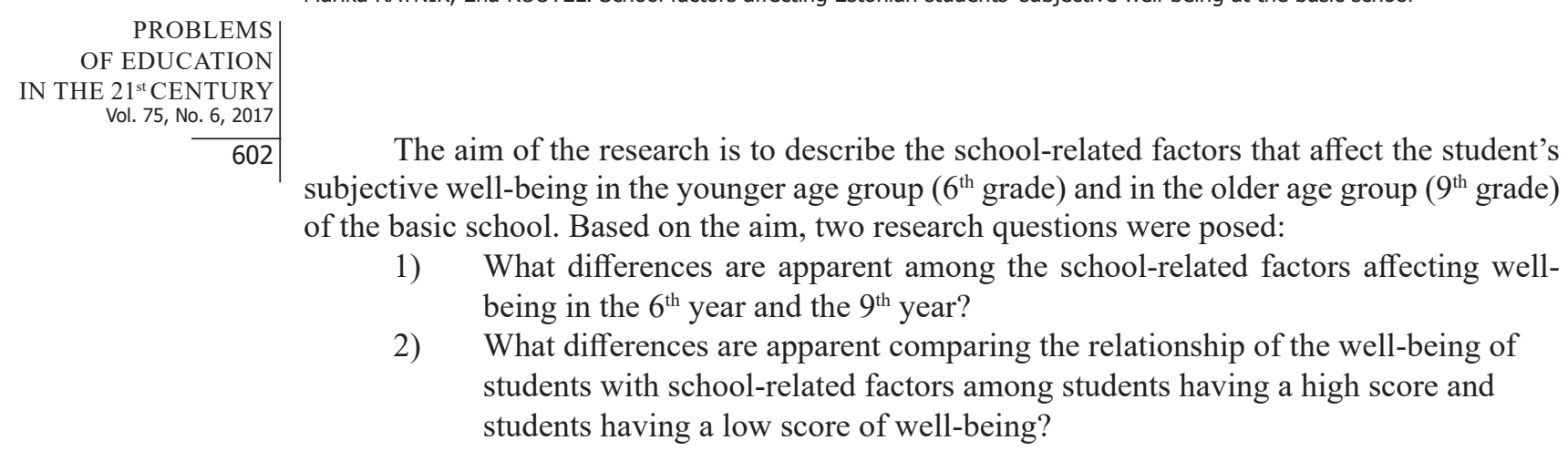

\section{Methodology of the Research}

A quantitative research was carried out on the basis of a semi-structured questionnaire focusing on perceived school relationships, learning environment, academic performance and subjective well-being. The research was conducted in spring 2011. The sample included schools with following profiles: four schools with a health promotion bias, four ordinary schools and six schools with an art bias. The number of schools with an art bias was bigger because of the smaller number of students.

\section{Sample}

The research included $6^{\text {th }}$ grade and $9^{\text {th }}$ grade students from 14 general education schools with Estonian study language, a total of 934 students including 419 (44.9\%) boys and 499 (52.8\% girls). The respondents were aged $12-17$ years. The number of the $6^{\text {th }}$ grade students was $490\left(52 \%\right.$ of the sample), with average age being 12.5 years, and the number of the $9^{\text {th }}$ grade students was 444 ( $48 \%$ of the sample), with average age being 15.5 .

\section{Research Procedure and Ethical Aspects}

First, the directors of the selected schools $(n=14)$ were contacted by e-mail, introducing the goals and ethical principles of the research, and asking for the permission to conduct the research in their schools. Only these schools were included in the sample, the directors of which permitted the questionnaire, therefore the sample can be considered a convenience sample. The research was conducted during the school hours and in all schools by the first author of this paper. The schools were allowed to have a representative present during the conduct of the research, but mostly none were sent. The research questionnaire was voluntary for the students. Before starting with the questionnaire, its goals and an overview of its content were introduced to the students. Those who did not wish to fill in the questionnaire, stayed in the classroom but had free time. The presence of the research conductor provided the students with the opportunity to get clarifications of the content of questions if needed. The filled-in questionnaires were collected by the conductor; they were not shared with anyone in the schools. To ensure the anonymity of the data, the filled-in questionnaires were encoded per school and per student.

\section{Instruments}

Well-being. The students' well-being was measured by the 5-item World Health Organization (WHO, 1998) Well-Being Index (WHO-5) which is a short and generic global rating scale. WHO-5 is a positively worded scale designed to assess emotional well-being within the previous two weeks, covering positive mood, vitality, and general interest. The scale has adequate validity both as a screening tool for depression and as an outcome measure in clinical trials, and has been applied successfully as a generic scale for well-being across a wide range of study fields (Topp, Østergaard, Søndergaard, \& Bech, 2015). WHO-5 is validated in Estonian language (Sisask, Värnik, Kõlves, Konstabel, \& Wasserman, 2008). The five items 
are: (a) being in good spirits, (b) feeling relaxed (c) having energy (d) waking up fresh and rested, (e) being interested in things. Each of the five items is rated on a 6-point Likert scale from 0 (= not present) to 5 (= constantly present). The results are in the range of $0-25$ where higher scores (13-25) indicate a high level of well-being. The findings of the review by Topp, Østergaard, Søndergaard and Bech (2015) show that the WHO-5 is a highly useful tool that can be applied to compare well-being between groups. For adolescents, the WHO-5 Well-Being Scale has been used by e.g. de Wit, Pouwer, Gemke, Delemarre van de Waal and Snoek (2007; Cronbach's alpha of the scale was 0.82), and Yallop, McDowell, Koziol-McLain and Reed (2013).

The WHO-5 Well-Being Index was also used in the international SEYLE study of students (Carli et al., 2013); 1,036 Estonian students participated in the study; its Cronbach`s alpha was 0.76. In the SEYLE study (Lumiste, 2011) Estonian students aged 14-15 years were asked about their mental health and their health-related and risk-related behaviour; it turned out that $88 \%$ of the respondents had a high level of subjective well-being as measured by the WHO-5 Well-Being Index; 12\% of the students had a subjective well-being level below the critical threshold.

For school factors, questions from earlier studies of Estonian students' life and circumstances (Rüütel \& Pill, 2008) and from the school related well-being profile questionnaire by Konu and Lintonen (2006) were used.

The questions related to perceived school relationships formed five summary indicators by factor analysis: relationships with teachers (it is easy to communicate with teachers; teachers encourage me to express my opinion in the classroom; most teachers are friendly; most teachers are interested in how I am doing; teachers treat me fairly; the feedback from teachers inspires me to make an effort for better results; $\alpha=0.83$ ); relationships with other students (it is easy to communicate with schoolmates; schoolmates accept me as I am; I get along well with my classmates; $\alpha=0.79$ ); pro-social behaviour of classmates (classmates help each other with homework; classmates help each other with problems; classmates intervene if someone is being bullied; $\alpha=0.80$ ); fair rules of behaviour (the school has certain rules for behaving in problem situations; the school's rules are reasonable; the school's punishments are fair; $\alpha=$ 0.80); parents' relationships with the school (parents value my schoolwork; parents are willing to come to the school to discuss with teachers if necessary; $r=0.46 ; p<.001$. Five options for responses were provided $(1=$ fully agreed; $2=$ partly agreed; $3=$ so-so; $4=$ partly disagreed; 5 = fully disagreed). Two separate questions were used to study bullying behaviour: "How often have you been bullied at school during this academic year?" and "How often have you taken part in bullying other students during this academic year?" (options for responses: 1 = not at all; 2 = on some occasions; $3=2-3$ times a month; $4=$ about once a month; $5=$ several times a month).

Four indicators were used to determine the perceived learning environment. Students were asked to assess the study load $(1=$ always too high; $2=$ sometimes too high; $3=$ suitable; 4 = sometimes too low; 5 = always too low). School's development was studied with the following question: "Have you experienced that the school becomes better?" ( 1 = not at all; 2 = rarely; 3 $=$ often). The enjoyment of classroom lessons was studied with the following question: "What do you generally feel when going to classes?" ( 1 = I gladly go to most classes; 2 = there are classes where I gladly go to; 3 = I am uncomfortable with going to most classes). Help from the school was studied with the following question: "Is it easy to obtain help from the school for your worries and problems?" ( 1 =yes, 2 = rather yes; 3 = rather no; $4=$ no).

As an indicator of academic performance, the students were asked to state their average grade of all subjects for the latest academic quarter. In the Estonian grading system, 5 is the best grade. 
Marika RATNIK, Eha RÜÜTEL. School factors affecting Estonian students' subjective well-being at the basic school

PROBLEMS

OF EDUCATION

IN THE $21^{\text {st }}$ CENTURY

Vol. 75 , No. 6,2017

604

Data Analysis

Anova dispersion analysis was used for comparison of groups (low/high well-being and $6^{\text {th }}$ and $9^{\text {th }}$ grade). Multiple regression analysis was used to find the predictors of perceived well-being.

\section{Results of Research}

The analysis is presented in two age groups because no statistically significant gender differences were apparent. The average WHO-5 score was 17.2 for boys $(\mathrm{SD}=4.9)$; 15.8 for girls $(\mathrm{SD}=4.8) ; \mathrm{t}=1.37, \mathrm{p}=.7$.

The Relations between the Well-Being of Students and School-Related Factors for Students with Low and High Well-Being

Table 1 shows the average assessments given to school-related factors by the $6^{\text {th }}$ year and the $9^{\text {th }}$ year students with high and low well-being, as well as their differences and mutual interactions. The share of students with low well-being was similar in both age groups: $22 \%$ in the 6 th year and $25 \%$ in the $9^{\text {th }}$ year.

Table 1. The differences and mutual interactions of the 6th year and the 9th year student groups with high and low well-being (ANOVA 2-factor dispersion analysis).

\begin{tabular}{|c|c|c|c|c|c|c|c|}
\hline \multirow[b]{2}{*}{ Variable } & \multicolumn{2}{|c|}{$\begin{array}{l}\text { Low well-being } \\
\text { WH05 0-12 }\end{array}$} & \multicolumn{2}{|c|}{$\begin{array}{l}\text { High well-being } \\
\text { WHO5 13-25 }\end{array}$} & \multicolumn{2}{|c|}{ Main effect $F$} & \multirow[b]{2}{*}{ Inter-action (F) } \\
\hline & $\begin{array}{l}\text { 6th year } \\
n=91 \\
\text { M/SD }\end{array}$ & $\begin{array}{l}\text { 9th year } \\
n=109 \\
M / S D\end{array}$ & $\begin{array}{l}\text { 6th year } \\
n=333 \\
M / S D\end{array}$ & $\begin{array}{l}\text { 9th year } \\
n=332 \\
M / S D\end{array}$ & year & $\begin{array}{l}\text { Well- } \\
\text { being } \\
\text { group }\end{array}$ & \\
\hline \multicolumn{8}{|l|}{$\begin{array}{l}\text { Perceived school } \\
\text { relationships } \\
\end{array}$} \\
\hline $\begin{array}{l}\text { Relationships with } \\
\text { teachers2 }\end{array}$ & $19.9 / 4.8$ & $17.9 / 4.2$ & $15.7 / 4.9$ & $15.2 / 4.5$ & $9.9^{* *}$ & $82.9^{\star \star \star}$ & $F(1,466)=5.32^{*}$ \\
\hline $\begin{array}{l}\text { Relationships with } \\
\text { other students } 2\end{array}$ & $8.6 / 3.6$ & $7.7 / 4.0$ & $6.3 / 2.9$ & $5.8 / 2.6$ & $7.7^{* *}$ & $74.4^{\star \star \star}$ & $F(1,480)=0.67$ \\
\hline $\begin{array}{l}\text { Pro-social behaviour } \\
\text { of classmates } 2\end{array}$ & $9.0 / 3.0$ & $8.1 / 3.2$ & $7.1 / 3.0$ & $6.8 / 2.7$ & $6.1^{*}$ & $45.6^{\star \star \star}$ & $F(1,477)=2.87$ \\
\hline $\begin{array}{l}\text { Fairness of the rules } \\
\text { of behaviour } 2\end{array}$ & $19.5 / 5.1$ & 18.8/4.6 & $15.9 / 5.2$ & $16.7 / 5.0$ & 0.004 & $47.1^{1 * \star}$ & $F(1,480)=6.5^{*}$ \\
\hline $\begin{array}{l}\text { Parents' relation- } \\
\text { ships with the } \\
\text { school2 }\end{array}$ & $4.7 / 2.1$ & $4.9 / 2.4$ & $3.8 / 1.9$ & $3.6 / 1.9$ & 2.3 & $51.7^{\star \star \star}$ & $F(1,474)=0.37$ \\
\hline $\begin{array}{l}\text { Bullied by school- } \\
\text { mates } 2\end{array}$ & $2.4 / 1.4$ & $1.5 / 0.9$ & $1.8 / 1.1$ & $1.3 / 0.8$ & $69.9^{* * *}$ & $24.6^{* \star *}$ & $F(1,482)=2.06$ \\
\hline $\begin{array}{l}\text { Participated in bul- } \\
\text { lying2 }\end{array}$ & $1.9 / 1.1$ & $1.5 / 0.9$ & $1.7 / 0.9$ & $1.4 / 0.8$ & $20.3^{* *}$ & $5.3^{*}$ & $F(1,482)=1.01$ \\
\hline \multicolumn{8}{|l|}{$\begin{array}{l}\text { Perceived learning } \\
\text { environment }\end{array}$} \\
\hline Study load1 & $2.0 / 0.7$ & $2.1 / 0.7$ & $2.5 / 0.6$ & $2.5 / 0.8$ & 0.1 & $59.3 \%$ & $F(1,616)=1.61$ \\
\hline $\begin{array}{l}\text { School's develop- } \\
\text { ment2 }\end{array}$ & $1.8 / 0.6$ & $1.9 / 0.6$ & $2.1 / 0.6$ & $2.0 / 0.7$ & 0.03 & $24.3^{\star \star \star}$ & $F(1,622)=2.77$ \\
\hline $\begin{array}{l}\text { Enjoyment of class- } \\
\text { room lessons }\end{array}$ & $2.1 / 0.6$ & $2.1 / 0.6$ & $1.7 / 0.6$ & $1.7 / 0.6$ & 0.1 & $85.2^{\star \star \star}$ & $F(1,607)=0.04$ \\
\hline $\begin{array}{l}\text { Help from the } \\
\text { school2 }\end{array}$ & $3.1 / 0.8$ & $3.1 / 0.8$ & $2.4 / 0.9$ & $2.5 / 0.8$ & 0.2 & $97.1^{* \star *}$ & $F(1,617)=0.82$ \\
\hline $\begin{array}{l}\text { Perceived academic } \\
\text { performance }\end{array}$ & & & & & & & \\
\hline Average grade 1 & $4.1 / 0.7$ & $3.9 / 0.65$ & $4.2 / 0.65$ & $4.0 / 0.61$ & $12.6^{\star * \star}$ & $4.4^{* *}$ & $F(1,464)=1.65$ \\
\hline
\end{tabular}


Statistical differences based on well-being groups were apparent for all studied indicators; the most significant difference occurred between the help obtained from school and the enjoyment of classroom lessons, as well as between the relationships with teachers and with other students, showing a significantly better perceived situation in the group of high wellbeing. There is also a clear difference between the age groups with high and low well-being, indicating that the relationships with teachers are better and there is more pro-social behavior of classmates in the 9 th year compared to the 6th year. Relationships with teachers also indicate the interaction between age group and the well-being group, referring to a larger difference between the average scores of the age groups in the low well-being group and highlighting that the relationships with teachers are better in the high well-being group and in the 9th year.

Differences independent from the age group were apparent between well-being groups concerning two indicators of the perceived school relationships - the fairness of the rules of behaviour, and the parents' relationship with the school - and concerning all indicators of the perceived learning environment - the study load, the school's development, the enjoyment of classroom lessons, and the help obtained from school. There were no differences between age groups concerning the fairness of the rules of behaviour. Yet, the analysis of well-being groups highlighted the interaction between the age group and the well-being group - the high wellbeing group of the $6^{\text {th }}$ year perceived the rules of behaviour as more fair and the same year's low well-being group as less fair than the relevant groups in the $9^{\text {th }}$ year.

\section{School-Related Factors Predicting Well-Being}

All 12 variables were included as independent variables in the multiple regression analysis, in order to determine the school-related factors predicting the students' well-being in the $6^{\text {th }}$ and the $9^{\text {th }}$ year. For $6^{\text {th }}$ year students, their well-being was predicted by (Table 2): relationships with teachers, relationships with other students, help obtained from the school, and parents' relationships with the school; the latter is in the model as a statistically non-significant predictor. The model describes $23 \%$ of the variance.

\section{Table 2. The regression model of school-related factors predicting the subjective well-being of $6^{\text {th }}$ year students.}

\begin{tabular}{llllll}
\hline Variable & BETA & $\begin{array}{l}\text { St. error of } \\
\text { BETA }\end{array}$ & $\mathbf{B}$ & St. error of B & $\mathbf{t}(\mathbf{8 2 8})$ \\
\hline Intercept & & & 26.76 & .84 & $31.78^{\text {*** }}$ \\
\hline Relationships with teachers & -.28 & .05 & -.28 & .05 & $-5.53^{\text {** }}$ \\
\hline Relationships with other students & -.15 & .05 & -.24 & .07 & $-3.37^{\text {** }}$ \\
\hline Help obtained from the school & -.15 & .05 & -.83 & .28 & $-2.99^{* *}$ \\
\hline Parents' relationships with the school & -.07 & .05 & -.21 & .13 & -1.60 \\
\hline$R^{2}=0.24 ;$ adjusted $R^{2}=0.23 ; p<.000 ; n=408 *$ & & & &
\end{tabular}

$R^{2}=0.24 ;$ adjusted $R^{2}=0.23 ; p<.000 ; \mathrm{n}=408 ;$

${ }^{*} p<.05 ;{ }^{* *} p<.01 ;{ }^{* * *} p<.001$

For the $9^{\text {th }}$ year students, the same school-related factors predicting well-being were apparent (Table 3): help obtained from the school, relationships with other students, relationships with teachers, and parents' relationships with the school. The model describes 19\% of the variance. 
Marika RATNIK, Eha RÜÜTEL. School factors affecting Estonian students' subjective well-being at the basic school

\section{PROBLEMS \\ OF EDUCATION \\ Table 3. The regression model of school-related factors predicting the subjective well-being of the $9^{\text {th }}$ year students.}

\begin{tabular}{llllll}
\hline Variable & BETA & $\begin{array}{l}\text { St. error of } \\
\text { BETA }\end{array}$ & $\mathbf{B}$ & $\begin{array}{l}\text { St. error } \\
\text { of B }\end{array}$ & $\mathrm{t}(\mathbf{8 2 8})$ \\
\hline Intercept & & & 25.56 & .60 & $42.40^{* * *}$ \\
\hline Help obtained from the school & -.22 & .05 & -1.14 & .27 & $-4.18^{\star * *}$ \\
\hline Relationships with other students & -.20 & .05 & -.28 & .07 & $-4.12^{\star * *}$ \\
\hline Relationships with teachers & -.15 & .05 & -.14 & .05 & $-2.83^{* *}$ \\
\hline Parents' relationships with the school & -.06 & .05 & -.14 & .11 & -1.19 \\
\hline
\end{tabular}

$R^{2}=.20 ;$ adjusted $R^{2}=0.19 ; F(4,395)=24.41 ; p<.000 ; \mathrm{n}=400$

${ }^{*} p<.05 ;{ }^{* *} p<.01 ;{ }^{* * *} p<.001$

When comparing the regression models of the $6^{\text {th }}$ and the $9^{\text {th }}$ year, the models are similar concerning both variables and the descriptive capacity $\left(23 \%\right.$ of variance for the $6^{\text {th }}$ year, $19 \%$ for the $9^{\text {th }}$ year); the student's relationships with teachers are the most significant predictor and the parents' relationships with the school are the least significant predictor in both models. A difference can be noted for the $9^{\text {th }}$ year as an increase of the significance of help obtained from the school. Support from classmates is not a predictor for either age group; yet, a wider indicator of social relations i.e. relationships with other students are.

\section{Discussion}

This research focuses on the relationship between the students' subjective well-being and the specific school-related factors. The data analysis was centered on different dispersions; the relationships of the factors of perceived school relationships, perceived learning environment and academic performance to the student's well-being were observed.

The analysis highlighted the factors differentiating between well-being groups and the factors predicting well-being. The factors differentiating between well-being groups were divided into factors related with the age group and factors independent from it. The schoolrelated factors independent from the age group, differentiating high well-being group from the low well-being group, were the help obtained from the school, the enjoyment of the classroom lessons, the parent's better relationships with the school, the perceived school's development, and the fairness of the school's rules. The differences resulting from the age group indicate to the more positive assessment of school-related factors in the older age group - better relationships with teachers and other students, less bullying behaviour, more pro-social relationships with classmates. In the dynamics of school relationships, changes at the level of both classroom and school-level relationships take place upon transitioning to the third stage of education. On the one hand, it is related with changes taking place in the teaching culture, as an individual approach is replaced with engaging and instructing the entire class as a whole. On the other hand, the relationship changes stem from the fact that in the middle stage of adolescent years, dyad-based relationships are replaced with group relationships while social comparison and mutual competition are becoming more important. Also, relationships with "other important" adults like e.g. teachers gain importance, because at that stage of development, adolescents try to distance themselves from their parents (Di Stasio, Savage \& Burgos, 2016).

A decrease of bullying behaviour upon transitioning from the early to the middle stage of adolescence is also highlighted by Troop-Gordon (2017), and it was also shown by the study of health behaviour among 11 to 15 years old Estonian students (Aasvee, et al., 2016). One of the reasons for the reduction in bullying behaviour may also be the drop-out of students, incl. those connected to bullying, from the school at that age, which in turn may be related with the phenomenon that teenagers find companions at school on the basis of similarity to 
themselves, e.g. on the basis of their school engagement (Kindermann, 2007). This research does not discuss the backgrounds of bullying behaviour, but there seems to be an important connection with a study by Di Stasio et al. (2016), which indicates that at the middle adolescent age, bullying behaviour at school is more related to relationships outside the classroom. This may also explain the results showing higher main effect of the well-being group in the case of the relationship with other students, while the pro-social behaviour of classmates remained a less important factor and differentiator of well-being groups. The impact of school-related relationships outside the classroom to the well-being has been indicated by several earlier studies (Danielson, Samdal, Hetland \& Wold, 2009; Uusitalo-Malmivaara, 2012; Casas, et al., 2013; Newland et al., 2015). Eccles and Roeser (2011) stress the effect of a same-age group in the school environment on adolescents' behaviour and their personal and social identity. The importance of the relationships with schoolmates, as found in this research, indicates that more research of social relationships at various levels (school, classroom) in the school environment should be conducted while clearly differentiating between them.

Based on the research results, a connection related to well-being can be highlighted students establish relationships supportive of well-being not only within their own classroom, and it is rather the wider communication culture at school that supports a student's wellbeing. Within this research, the wider impact of the school is also indicated by the result that obtaining help from the school (the school's pro-social organization) is more important for the student's well-being than the pro-social behaviour of classmates and is also a more important factor differentiating between the low and the high well-being group. This brings into focus the school's willingness and capability to offer the students help corresponding to their needs. This result is also supported in a research by Renshaw, Long and Cook (2014), which also highlighted that the subjective well-being of students is affected by both the school's social support and the school's pro-social organization. The fairness of the school's rules of behavior (which can be conditionally classified as an indicator of the school's pro-social organisation) also turned out to be an important characteristic differentiating between well-being groups, although it was not a predictor of the students' well-being.

The current research highlighted a similar regression model predicting subjective wellbeing in the both age groups, describing $23 \%$ of the variance for the $6^{\text {th }}$ year and $19 \%$ of the variance for the $9^{\text {th }}$ year. In both age groups, students' relationships with teachers and obtaining of help from the school were shown to be important predictors of well-being as it also been found by several other authors (Suldo et al., 2008; Suldo et al., 2009; Bird et al., 2012; Simmons et al., 2015). The third important predictor was the student's relationships with schoolmates, drawing attention to the school-related relationships' quality of valuing one's person. In adolescence, various interpersonal relationships are important, and friendships may no longer be related to classmates only but to wider school-related connections instead. Adolescents with more interpersonal relationships feel themselves less lonely, they have fewer negative emotions and they use more social support (Lennarz et al., 2016).

The fourth predictor in the model was the parents' relationships with the school, which was also an indicator differentiating between the well-being groups. In the regression model of the $9^{\text {th }}$ year, the parents' relationships with the school were a statistically important predictor. This hints at the importance of the parents' engagement with the school not only in the younger age group where the parents' help in and knowledge of the school's matters is considered natural and necessary. The parents' school engagement was also an important predictor of the students' well-being in a study by Suldo et al. (2008). In that study, engagement was considered to be the communication between the school and the home and the parents' visits to the school.

Several studies indicate that school-related subjective well-being is not a value in and of itself, instead affecting significantly the students' adaptation, academic performance, school behaviour and the satisfaction of their main psychological needs at school (Elmore, 2007; Huebner et al., 2006). Tian et al. (2015) stresses the interactive role of social contexts and personal factors in affecting the well-being of adolescents. The notes and interpretations by the 
Marika RATNIK, Eha RÜÜTEL. School factors affecting Estonian students' subjective well-being at the basic school

\begin{abstract}
PROBLEMS
OF EDUCATION

IN THE $21^{\text {st }}$ CENTURY Vol. 75, No. 6,2017

608 students themselves are critical mediators of school-related factors and the students' feelings, beliefs and behaviour (Eccles et al., 2011). The knowledge about which factors of the school environment influence the students' well-being at the classroom and the school level, help the school as an institution make a sustainable contribution to the assessment and improvement of precisely those aspects.
\end{abstract}

\title{
Conclusions
}

As of from 2010, Estonian education system has been paying more attention to students' well-being, precisely through national measures. The results of this research demonstrate which factors of the school environment should be constantly assessed and focused on. The knowledge about the factors supporting the well-being of different age groups at the classroom and the wider school level enables to plan interventions and changes in the school environment for positive empowerment of the students. Undoubtedly, the student's well-being is also significantly affected by personal and other contextual factors. Nevertheless, the results of the research clearly show that the key aspect to the student's well-being is the school's capability to offer help corresponding to the student's needs, to support the teachers' coping with the multitude of relationships, and to find a way to communicate the school's values to the parents on the basis of their child's contribution to the school's functioning.

It would be needed to continue the research, focusing on the possibilities of receiving support from the school and improving relations in the school environment, involving both students and the specialists of the support system of the schools as target groups.

\section{References}

Aasvee, K., Liiv, K., Eha, M., Oja, 1., Härm, T., \& Streiman, K. (2016). Eesti kooliõpilaste tervisekäitumise uuring. 2013/2014. õppeaasta uuringu raport [Health behaviour of Estonian school-aged children. Study report of 2013/2014 study year]. Tallinn: Tervise Arengu Instituut.

Bird, J. M., \& Markel, R. S. (2012). Subjective well-being in school environments: Promoting positive youth development through evidence-based assessment and intervention. American Journal of Ortopsychiatry, 82 (1), 61-66.

Carli, V., Wasserman, C., Wasserman, D., Sarchiapone, M., Apter, A., Balazs, J.,...Hoven, C. W. (2013). The saving and empowering young lives in Europe (SEYLE) randomized controlled trial (RCT): Methodological issues and participant characteristics. BMC Public Health, 13, 479. DOI: 10.1186/1471-2458-13-479.

Casas, F., Baltatescu, S., Bertran, I., Gonzalez, M., \& Hatos, A. (2013). School satisfaction among adolescents: Testing different indicators for its measurement and its relationship with overall life satisfaction and subjective well-being in Romania and Spain. Social Indicator Research, 111, $665-681$

Danielson, A. G., Samdal, O., Hetland, J., \& Wold, B. (2009). School-related support and student perceived life satisfaction. The Journal of Educational Research, 102, 303-320.

De Wit M., Pouwer, F., Gemke, R. J. B. J., Delemarre van de Waal, H. A., \& Snoek, F. J. (2007). Validation of the WHO-5 Well-Being Index in adolescents with type 1 diabetes. Diabetes Care, 30 (8), 20032006.

Diener, E. (1984). Subjective well- being. Psychological Bulletin, 95, 542-575.

Di Stasio, M. R., Savage, R., \& Burgos, G. (2016). Social comparison, competition and teacher-student relationships in junior high school classrooms predicts bullying and victimization. Journal of Adolescence, 53, 207-216.

Eccles, J. S., \& Roeser, R. W. (2011). Schools as developmental contexts during adolescence. Journal of Research on Adolescence, 21 (1), 225-241.

Elmore, R. (2007). School reform from the inside out: Policy practice and performance. Cambridge, MA: Harvard Education Press.

Engels, N., Aelterman, A., Petegem, K., \& Schepens, A. (2004). Factors with influence the well-being of pupils in Flemish Secondary Schools. Educational Studies, 30, 127-144. 
Gilman, R., Huebner, E.S. (2006). Characteristics of adolescents who report very high life satisfaction. Journal of Youth and Adolescence, 35, 311-319.

Gobina, I., Zaborskis, A., Pudule, I., Kalnins, I., \& Villerusa, A. (2008). Bulying and subjective health among adolescents at school in Latvia and Lithuania. International Journal of Public Health, 53, 272-276.

Holfve-Sabel, M-A. (2014). Learning, interaction and relationships as components of student well-being: Differences between classes from student and teacher perspective. Social Indicator Research, 119, 1535-1555.

Huebner, E. S. (1994). Preliminary development and validation of a multidimensional life satisfaction scale for children. Psychological Assessment, 6, 149-158.

Huebner, E. S., Gilman, R., Reschly, A. L., \& Hall, R. (2009). Positive schools. In S. J. Lopez, \& C. R. Snyder (Eds.), Oxford handbook of positive psychology (2nd Ed.) (pp. 561-578). Oxford: University Press.

Huebner, E. S., Suldo, S. M., \& Gilman, R. (2006). Life satisfaction. In G. G. Bear \& K. M. Minke (Eds.), Children's needs: Part III. Development, prevention, and intervention (pp. 357-368). Bethesda, MD: National Association of School Psychologists.

Ilves, K. (2013). Laps hariduses ja noorsootöös [Child in education and youth work]. Rmt. Heinsaar, J. (Toim.), Laste heaolu (lk. 84-106). [Children's Well-being].Tallinn: Statistikaamet.

Inchley, J., Currie, D., Taryn, Y., Samdal, O., Torbjorn, T., Augustson, L.,...Barnekow, V. (2016). Health behaviour in school-aged children HBSC study. International Report from the 2013/0214 survey. World Health Organization.

Karu, M., Turk, P., Suvi, H., \& Biin, H. (2012). Lapse õiguste ja vanemluse monitooring. Laste ja täiskasvanute küsitluse kokkuvõte [Child rights and parenthood monitoring. Summary of children and adult survey]. Tallinn: Poliitikauuringute Keskus Praxis.

Kindermann, T. A. (2007). Effects of naturally existing peer groups on changes in academic engagement in a cohort of sixth graders. Child Development, 78 (4), $1186-1203$.

Konu, A. I., Lintonen, T. P., \& Rimpelä, M. K. (2002). Factors associated with schoolchildren`s general subjective well-being. Health Education Research, 2, 155-165.

Konu, A. I., \& Lintonen, T. P. (2006). School well-being in Grades 4-12. Health Education Research, 21 (5), 633- 642.

Laes, T-L., Krusell, S. Reinomägi, A., Toros, K. (2013). Lapsed eri keskkondades [Children in different environments]. Rmt. Heinsaar. J (Toim.), Laste heaolu (lk. 13-30). [Children's Well-being]. Tallinn: Statistikaamet.

Lennarz, H. K., Roekel, E., Kuntsche, E., Lichtwarck-Aschoff, A., Hollenstein, T., Engels, R. C. M. E., \& Granic, I. (2016). Associations between interpersonal relationships and negative affect in adolescents: An experience sampling study on the role of trait coping. Swiss Journal of Psychology, 75 (2), 71-79.

Li, Y., \& Lerner, R. M. (2011). Trajectors of school engagement during adolescence: Implications for grade, depression, delinquency, and substance use. Developmental Psychology, 47, 233-347. doi:10.1037/a0021307.

Liu, W., Mei, J., Tian, L., \& Huebner, S. E. (2016). Age and Gender Differences in the relation between school-related social support and subjective well-being in school among students. Social Indicator Research, 3, 1065-1083.

Lumiste, K. (2011). Seyle õpilaste ja õpetajate baasuuringu tulemused. Vaimne tervis ja riskikäitumine [Results of the baseline survey on students and teachers at Seyle. Mental health and risk behaviour]. Tallinn: Eesti-Rootsi Vaimse tervise ja Suitsidioloogia Instituut.

Lewis, A. D., Huebner E. S., Malone., P. S., \& Valois, R. F. (2011). Life satisfaction and student engagement in adolescents. Journal Youth and Adolescence, 40, 249-262.

Newland, L.A., Lawler, J.M., Giger, J.T., Roh, S. \& Carr, E.R. (2015). Predictors of children's subjective well- being in rural communities. Child Indicator Research, 1 (8), 177-198.

Noble, T., McGrath, H., Wyatt, T., Carbines, R., \& Robb, E. (2008). Scoping study into approaches to student wellbeing. Australia: Australian Catholic University.

Pilkauskaite-Valickiene, R., \& Gabrilaviciute, I. (2015). The role of school context on subjective well-being and social well-being in adolescence. Procedia-Social and Behavioural Sciences, 191 (2), 2588-2592.

Renshaw, T. L., Long, A.C., \& Cook, C.R. (2014). Assessing adolescents' positive psychological functioning at school: Development and validation of the Student Subjective Wellbeing Questionnaire. School Psychology Quarterly, 30 (4), 534-552. 
Marika RATNIK, Eha RÜÜTEL. School factors affecting Estonian students' subjective well-being at the basic school

\section{PROBLEMS \\ OF EDUCATION \\ IN THE $21^{\text {st }}$ CENTURY \\ Vol. 75, No. 6, 2017}

610

Rüütel, E., \& Pill, E. (2008). Õpilase elu-olu 1998-2007. Küsitluse KOOLITUGI kokkuvõte [A student's life 1998-2007. Summary of the survey SCHOOL SUPPORT]. Tallinn: Tallinna Ülikool, Tallinna Haridusamet.

Salmela-Aro, K., \& Tuominen-Soini, H. (2010). Adolescents' life satisfaction during the transition to post-comprehensive education: Antecedents and consequences. Journal of Happiness Studies, 11, 683701.

Salmela-Aro, K., Moeller J., Schneider, B., Spicer, J., \& Lavonen, J. (2016). Integrating the light and dark sides of student engagement using person-oriented and situation-specific approaches. Learning and Instruction, 43, 61-70.

Salmela-Aro, K., \& Upadyaya, K. (2012). The schoolwork engagement inventory: Energy, dedication and absorption (EDA). European Journal of Psychological Assessment, 28, 60-67.

Samdal, O., Nutbeam, D., Wold, B., \& Kannas, L. (1998). Achieving health and educational goals through schools: A study of the importance of the school climate and student's satisfaction with school. Health Education Research, 13, 383-397.

Simmons, A. C., Graham, A., \& Thomas, N. (2015). Imagining an ideal school for wellbeing: Locating student voice. Journal of Educational Change, 16 (2), 129-144.

Sisask, M., Värnik, A., Kõlves, K., Konstabel, K., \& Wasserman, D. (2008). Subjective psychological well-being (WHO-5) in assessment of the severity of suicide attempt. Nordic Journal of Psychiatry, 62, 431-435.

Soutter A. K. (2011). What can we learn about wellbeing in school? Journal of Student Wellbeing, 5 (1), $1-21$.

Suldo, S. M., Shaffer, E.J., \& Riley, K. N. (2008). A social-cognitivebehavioral model of academic predictors of adolescents' life satisfaction. School Psychology Quarterly, 23, 56.

Suldo, S. M., Friedrich, A.F., White, T., Farmer, J., Minch, D., \& Michalowski, J. (2009). Teacher support and adolescent's subjective well- being: A mixed-methods investigation. School Psychology Review, 38, 67-85.

Tian, L. (2008). Developing scale for school well-being in adolescents. Psychology Development and Education, 3 (24), 100-107.

Tian, L., Chen, H., \& Huebner, E. S. (2014). The longitudinal relationships between basic psychological needs satisfaction at school and school-related subjective well-being in adolescents. Social Indicator Research, 119, 353-372.

Tian, L., Liu, B., Huang, S., \& Huebner, E. S (2013). Perceived social support and school well-being among Chinese early and middle adolescents: The mediational role of self-esteem. Social Indicators Research, 113 (3), 991-1008.

Tian, L., Zhao, J., \& Huebner, E. S. (2015). School-related social support and subjective well-being in school among adolescents: The role of self-system factors. Journal of AdolescenceJournal of Adolescence, 45, 138-148.

Topp, C. W., Østergaard, S.D., Søndergaard, S., \& Bech P. (2015). The WHO-5 Well-Being Index: A systematic review of the literature. Psychotherapy and Psychosomatics, 84, 167-176. DOI: $10.1159 / 000376585$.

Troop-Gordon, W. (2017). Peer victimization in adolescence: The nature, progression, and consequences of being bullied within a developmental context. Journal of Adolescence, 55, 116-128.

Tiliouine, H. (2015). School bylling victimisation and subjective well-being in Algeria. Child Indicator Research, 8, 113-150.

Uusitalo-Malmivaara, L. (2012). Global and school-related happiness in Finnish children. Journal of Happiness Studies, 13, 601-619.

WHO (1998). World Health Organization info package: Mastering depression in primary care. Frederiksborg: World Health Organization, Regional Office for Europe, Psychiatric Research Unit. http://www.gp-training.net/protocol/psychiatry/who/whodep.htm.

Yallop K, McDowell H, Koziol-McLain, \& Reed P. W. (2013). Self-reported psychosocial wellbeing of adolescent childhood cancer survivors. European Journal of Oncology Nursing, 17, 711-719. 
Marika RATNIK, Eha RÜÜTEL. School factors affecting Estonian students' subjective well-being at the basic school

PROBLEMS

OF EDUCATION

IN THE $21^{\text {st }}$ CENTURY

Vol. 75, No. 6, 2017

Received: November 08, 2017

Accepted: December 16, 2017

611

Marika Ratnik

Lecturer, School of Natural Sciences and Health of Tallinn University, Estonia.

E-mail: marika.ratnik@mail.ee

Website: www.tlu.ee

Eha Rüütel

Professor, School of Natural Sciences and Health of Tallinn University, Estonia.

E-mail: eha@tlu.ee

Website: www.tlu.ee 